\title{
Three-Enzyme Cascade Bioreactor for Rapid Digestion of Genomic DNA into Single Nucleosides
}

\author{
Junfa Yin, ${ }^{\dagger}$ Tian $\mathrm{Xu},{ }^{\dagger,}$ Ning Zhang, ${ }^{\dagger}$ and Hailin Wang ${ }^{*, \dagger, \dagger}$ \\ ${ }^{\dagger}$ State Key Laboratory of Environmental Chemistry and Ecotoxicology, Research Center for Eco-Environmental Sciences, Chinese \\ Academy of Sciences, Beijing 100085, China \\ ${ }^{*}$ University of Chinese Academy of Sciences, Beijing 100049, China
}

Supporting Information

ABSTRACT: Structure-based DNA modification analysis provides accurate and important information on genomic DNA changes from epigenetic modifications to various DNA lesions. However, genomic DNA strands are often required to be efficiently digested into single nucleosides. It is an arduous task because of the involvement of multiple enzymes with different catalytic acitivities. Here we constructed a three-enzyme cascade capillary monolithic bioreactor that consists of immobilized deoxyribonuclease I (DNase I), snake venom phosphodiesterase (SVP), and alkaline phosphatase (ALPase). By the use of this cascade capillary bioreactor, genomic DNA can be efficiently digested into single nucleosides with an increasing rate of $\sim 20$ folds. The improvement is mainly attributed to dramatically increase enzymatic capacity and activity. With a designed macro-porous structure, genomic DNA of 5-30 Kb $(\sim 1.6-10$ million Daltons) can be directly passed through the bioreactor simply by hand pushing or a low-pressure microinjection pump. By coupling with liquid chromatography-tandem mass spectrometry (LC-MS/MS), we further developed a sensitive assay for detection of an oxidative stress biomarker 8-oxo-7,8-dihydro-2'-deoxyguanosine (8-oxodG) in DNA. The proposed three-enzyme cascade bioreactor is also potentially applicable for fast identification and quantitative detection of other lesions and modifications in genomic DNA.
$\mathrm{E}$ xposure to chemical carcinogens may result in DNA damages, a key step toward the onset of cancer. ${ }^{1-4}$ DNA damages can occur via structural modification of the nucleosides and phosphate moieties in DNA chains. ${ }^{5}$ It is difficult to directly search for various modifications in genomic DNA since DNA strands are long biopolymers consisting of a large number of normal nucleosides (deoxyadenosine, dA; deoxygunosine, $\mathrm{dG}$; deoxycytidine, $\mathrm{dC}$; and thymidine monophosphates, $\mathrm{dT}$ ) interspersing with a small quantity of modified nucleosides (e.g., 5-methylcytosine, $5 \mathrm{mC}$ ) or trace modifications (e.g., 5hydroxymethylcytosine, 5-formalcytosine, and 5-carboxylcytosine). To determine these DNA modifications, genomic DNA samples were often required to be efficiently digested into mononucleotides or single nucleosides. ${ }^{6-10}$ Liquid chromatography-mass spectrometry (LC-MS) can explore whether nucleotide is modified, and is sensitive enough to quantify these modifications on DNA chains. ${ }^{9,11-15}$ For example, during LC-MS/MS analysis of global DNA methylation and hydroxylmethylation, genomic DNA was digested into the mixture of classical DNA nucleosides (dA, dT, dG, dC) and modified nucleosides. ${ }^{16-18}$ Recently, we discovered a new DNA modification in drosophila, N6-methyladenine. ${ }^{19}$ To accurately identify its structure and validate its identity, the Drosophila genomic DNA was also required to be digested into single nucleosides for high sensitivity analysis. Another example, identification and analysis of oxidative damaged DNA (e.g., 8- oxo-7,8-dihydro-2'-deoxyguanosine, 8-oxodG) completely digestion of genomic DNA to maximal release 8-oxodG was necessary for accurate 8-oxodG quantification. ${ }^{20-25}$ Analysis of nucleosides can provide increased sensitivity, accuracy and precision rather than detection of DNA polynucleotides or mononucleotides.

Of note, DNA digestion is very different from proteomic digestion, in which the proteins can be quickly digested into small peptides and amino acids by one enzyme (e.g., the potent enzyme trypsin), which can then be directly analyzed by LCMS. $^{26-32}$ Compared with the most commonly studied proteins, genomic DNA strands are much larger supramacromolecules, which possess molecular weight generally more than 10 million Daltions. To characterize chemical structural change of nucleotides in DNA or to quantify the stucturally changed nucleoties, long DNA chains are often required to be digested into single nucleosides facilitating followed MS analysis. Nevertheless, the digestion of genomic DNA into single nucleosides was required at least three enzymes, involving deoxyribonuclease (e.g., DNase P1 or DNase I), phosphodiesterase (e.g., snake venom phosphodiesterase, SVP), and alkaline phosphatase (ALPase). ${ }^{10,16-19,33-37}$ DNase I are applied to

Received: April 28, 2016

Accepted: June 24, 2016

Published: July 14, 2016 
cleave DNA into small oligonucleotides and mononucleotides, phosphodiesterases attack the $3^{\prime}$ - or $5^{\prime}$-terminal $\mathrm{OH}$-groups releasing $5^{\prime}$ - and $3^{\prime}$-mononucleotides respectively and ALPase are responsible for removing phosphate from the mononucleotides. However, this most commonly used approach has encountered some critical problems. Regarding the involvement of three enzymes in DNA digestion, the reaction buffer conditions, in particular $\mathrm{pH}$, are hard to control to satisfy all three enzymes. This makes the DNA digestion a timeconsuming and tedious process. For instance, incubation time of genomic DNA and three enzymes in solution is common 6$24 \mathrm{~h}$. In terms of 8-oxodG analysis, digestion for long time is likely to induce excessive amount of artificial oxidation of DNA sample, for example, formation of 8-oxodG from dG. On the other hand, since the enzymes and the digested DNA products are in the same solution, the removal of enzymes in samples by denaturation and ultrafiltration was required prior to LC-MS analysis. The cleaved-nucleobases may change (oxidation and isomerization) during this period. ${ }^{20}$ To minimize artificial formation of 8-oxodG, several complicated manipulations involving oxygen removal, a lower workup temperature and the elimination of transition metals by nitroxides or deferoxamine mesylate (DFO) have been applied. ${ }^{21,22}$

Recently, enzyme-immobilized bioreactors have been used in many applications including the chemical analysis of proteins, kinetic studies and biocatalysis. ${ }^{28-32,38-44}$ Online analysis platform included trypsin-immobilized reactor coupled to LCMS/MS or capillary electrophoresis (CE), which could digest proteins and identify peptides automatically, demonstrating an increasing stability and improved enzymatic activity of trypsin. ${ }^{40-44}$ Although the enzymes immobilized bioreactors work very well in proteomics analysis, at this moment, there is no data to tell if immobilized enzymes work for DNA digestion. We thus fabricated a snake venom phosphodiesterase-based capillary bioreactor that can digest oligodeoxynucleotides for mass spectrometry-based sequencing. ${ }^{45}$ By using such a SVP bioreactor, the sequence-specific modification of single strand oligodeoynucleotides induced by a ubiquitous pollutant acrolein was identified, demonstrating its promising applications in identification of sequence-specific damages in short oligonucleotides. In terms of the genomic DNA strands, however, there has no attempt been made in developing threeenzyme immobilized bioreactor for their completely digestion.

In this study, a novel DNA digestion system was developed by fabricating DNase I-SVP-ALPase cascade bioreactor. We immobilize DNase I, SVP, ALPase on the surface of capillary silica monoliths, and joint these three bioreactors successively to construct cascade bioreactors by which genomic DNA can be fast digested to nucleosides within $45 \mathrm{~min}$. By taking advantage of their good permeability, DNA solution can be directly injected into the cascade bioreactor simply by hand pushing or a low-pressure microinjection pump. The microliter samples were enabled to flow through bioreactors immobilized with enzymes of high density which can enormously enhance the enzymatic digestion efficiency. Moreover, the immobilization of DNase I, SVP, ALPase has greatly improved the stability of enzymes, making the bioreactor reusable. We further developed a bioreactor offline coupled LC-MS method for highly sensitive screening of oxidative stress biomarker 8 -oxodG induced by Fenton reaction in genomic DNA. This method is applicable for fast identification and quantitative detection of oxidative DNA damages in genomic DNA.

\section{EXPERIMENTAL SECTION}

Chemicals. Snake venom phosphodiesterase (SVP), calf thymus DNA (ct-DNA, type I), and poly(ethylene glycol) (PEG, 95\%) were purchased from Sigma-Aldrich Co. (St. Louis, MO). Deoxyribonuclease I (DNase I) was purchased from Sangon Biotech Co. (Shanghai, China). Alkaline phosphatase (ALPase) was purchased fom AppliChem (Darmstadt, Germany). 3-Amino-propyltrimethoxysilane (APTMS, 98\%) and tetramethoxysilane (TMOS, 98\%) were purchased from J\&K Chemica (Beijing, China). Other chemical were purchased from Sigma-Aldrich (St. Louis, MO).

Preparation of the Capillary Silica Monolith. The preparation monolith column was performed following the previous work. ${ }^{45}$ Briefly, fused silica capillary $(20 \mathrm{~cm}, 75 \mu \mathrm{m}$ i.d., $360 \mu \mathrm{m}$ o.d.) was washed with methanol and deionized water for about $1 \mathrm{~h}$. Then, the surface of capillary was activated by $0.1 \mathrm{M} \mathrm{NaOH}$ for $4 \mathrm{~h}$ and the residual alkali was neutralized using $0.1 \mathrm{M} \mathrm{HCl}$ for $1 \mathrm{~h}$. Finally, the activated capillary was dried by nitrogen at $60{ }^{\circ} \mathrm{C}$.

The sol-gel was prepared by mixing $2.0 \mathrm{~mL}$ of TMOS with $5.0 \mathrm{~mL}$ of acetic acid, which contained $0.44 \mathrm{~g}$ of PEG and 0.45 $\mathrm{g}$ of urea. The mixture was stirred in ice for $40 \mathrm{~min}$ and then injected into the silica capillary. After both ends of capillary sealed, the silica capillary was immersed into a water bath at 40 ${ }^{\circ} \mathrm{C}$ for $24 \mathrm{~h}$. Eventually, the monolith was heated at the gradient temperature from 40 to $120{ }^{\circ} \mathrm{C}$ for $5 \mathrm{~h}$.

Immobilization of DNase I, SVP, and ALPase onto the Monolith Column. DNase I was immobilized onto monolith column using the glutaraldehyde as a cross-linking agent, as previously reported. ${ }^{45}$ A solution containing APTMS, ethanol, and water $(5: 10: 90, \mathrm{v} / \mathrm{v})$ was injected into the monolith for $4 \mathrm{~h}$ and followed by deionized water rinsing for $1 \mathrm{~h}$. Then, $20 \%$ glutaraldehyde solution in $25 \mathrm{mM}$ phosphate buffer $(\mathrm{pH} 6.8$ ) was filled into monolith column for $4 \mathrm{~h}$ at $4{ }^{\circ} \mathrm{C}$ and washed with phosphate buffer. Ultimately, $5 \mathrm{mg} / \mathrm{mL}$ DNase I in $25 \mathrm{mM}$ phosphate buffer ( $\mathrm{pH}$ 6.8) was filled into the monolith for $4 \mathrm{~h}$. After immobilization of DNase I, the bioreactor was reduced with $2 \mathrm{mg} / \mathrm{mL} \mathrm{NaCNBH}$. DNase I bioreactor was stored in the $25 \mathrm{mM}$ phosphate buffer containing $0.02 \% \mathrm{NaN}_{3}$ at $4{ }^{\circ} \mathrm{C}$. The SVP and ALPase bioreactor was prepared by using the same method as DNase I bioreactor. Finally, DNase I $(20 \mathrm{~cm})$, SVP $(15 \mathrm{~cm})$ and ALPase $(15 \mathrm{~cm})$ bioreactors were cascaded in order with zero-volume steel unions (Valco, Switzerland).

Enzymatic Activity Assay. DNase I activity was determined by measuring the increase of absorbance response at $260 \mathrm{~nm}\left(A_{260}\right)$ using ct-DNA as the substrate. A solution of $200 \mathrm{ng} / \mu \mathrm{L}$ ct-DNA in phosphate buffer ( $\mathrm{pH} 5.0,2 \mathrm{mM} \mathrm{MgCl}_{2}$ and $2 \mathrm{mM} \mathrm{CaCl}_{2}$ ) was injected into the DNase I bioreactor for the substrate hydrolysis of $0.5,1.0,1.5,2.0,2.5 \mathrm{~min}$. DNA samples were pushed out and the absorbance at $260 \mathrm{~nm}$ were measured using a NanoDrop 2000 type UV spectrophotometer. SVP activity was determined by measuring concentration of $p$ nitrophenyl obtained from the SVP catalyzed hydrolysis of bis ( $p$-nitrophenyl) phosphate (NTP). A solution of $5 \mathrm{mM} \mathrm{NTP} \mathrm{in}$ $100 \mathrm{mM}$ Tris- $\mathrm{HCl}$ buffer ( $\mathrm{pH}$ 9.8) was pushed into the SVP bioreactor for substrate hydrolysis of $0.5,1.0,2.0,3.0$, $4.0 \mathrm{~min}$. Then the solution was pushed out, and absorbance was measured at $400 \mathrm{~nm}$ using a Nanodrop 2000. ALPase activity was determined by measuring concentration of $p$-nitrophenyl obtained from the ALPase catalyzed hydrolysis of $p$-nitrophenyl phosphate. The method was similar to SVP bioreactor. 
Genomic DNA Enzymatic Hydrolysis. The DNA samples were dissolved in $20 \mathrm{mM}$ Tris- $\mathrm{HCl}$ buffer $(\mathrm{pH}$ 7.6) containing $2 \mathrm{mM} \mathrm{CaCl}$ and $2 \mathrm{mM} \mathrm{MgCl}_{2}$, then injected into the bioreactor by a low-pressure microinjection pump, with injection volume of $12 \mu \mathrm{L}$. Then the reaction products were eluted from bioreactor by $20 \mathrm{mM}$ Tris- $\mathrm{HCl}$ buffer $(\mathrm{pH} 7.6)$ at flow rate of $1.3 \mu \mathrm{L} / \mathrm{min}$ until $60 \mu \mathrm{L}$ solutions were collected. Finally, $10 \mu \mathrm{L}$ of the digested DNA samples were directly subjected to HPLC-MS/MS for analysis of 8-oxodG.

As a contrast, DNA samples were digested in solution at 37 ${ }^{\circ} \mathrm{C}$ for $12 \mathrm{~h} .1 \mathrm{U}$ DNase I, $1 \mathrm{U}$ ALPase, $0.5 \mathrm{U}$ SVP, and $1 \mathrm{mM}$ DFO were added into $20 \mathrm{mM}$ Tris- $\mathrm{HCl}$ buffer $(\mathrm{pH} 7.6)$ containing $2 \mathrm{mM} \mathrm{CaCl}$ and $2 \mathrm{mM} \mathrm{MgCl}_{2}$. The digestion solutions were then passed through an ultrafiltration tube (MW cut off $3 \mathrm{kDa}$, Millipore) by centrifugation at $12000 \times g$ for 20 $\min$.

Cascade Bioreactor Coupled HPLC-MS/MS Analysis of 8-oxodG. HPLC-MS/MS analysis was performed on Agilent 1290 UHPLC system coupled with a G6410B triple quadrupole mass spectrometer (Agilent Technologies, Palo Alto, CA). A reversed-phase Zorbax Eclipse Plus C18 column $(2.1 \times 100$ $\mathrm{mm}, 1.8 \mu \mathrm{m}$, Aglient) was used for isocratic elution at a flow rate of $0.3 \mathrm{~mL} / \mathrm{min}$. The mass spectrometer was operated in the positive ion mode. A multiple reaction monitoring (MRM) mode was adopted for selective detection of 8-oxodG: $\mathrm{m} / \mathrm{z}$ $284.1 \rightarrow 168.0$ (collision energy, $5 \mathrm{eV}$ ) and $\left[{ }^{15} \mathrm{~N}_{5}\right]$-8-oxodG $289.1 \rightarrow 173.0(5 \mathrm{eV}) ; \mathrm{dG}: m / z 268.1 \rightarrow 152.0(5 \mathrm{eV})$ and $\left[{ }^{15} \mathrm{~N}_{5}\right]$-dG $273.1 \rightarrow 157.0(5 \mathrm{eV})$. Nitrogen was used for nebulization and desolvation gas. The desolvation gas was heated to $300{ }^{\circ} \mathrm{C}$ and delivered at a flow-rate of $9.0 \mathrm{~L} / \mathrm{min}$. The capillary voltage was set at $3500 \mathrm{~V}$. Each sample was at least analyzed for three times with an injection volume of $10 \mu \mathrm{L}$. The oxidative damages frequency was calibrated internally by the stable isotopic standards.

Calibration Curves, Accuracy, and Precision. A calibration curve is built by fitting the peak area ratio of $\gamma^{*} 8$ oxodG/dG $\left(\gamma=\left[{ }^{15} \mathrm{~N}_{5}\right]-\mathrm{dG} /\left[{ }^{15} \mathrm{~N}_{5}\right]\right.$-8-oxodG $)$ and concentration ratio of 8 -oxodG $/ 10^{6} \mathrm{dG}$. The ct-DNA containing high concentration level of 8-oxodG was prepared through Fenton reaction and then diluted by pristine ct-DNA to a series of concentrations of 8-oxodG (used as standard 8-oxodG solutions). The standard samples with different concentration of 8-oxodG (ranged from 32.9 to 1358.7 lesions per $10^{6} \mathrm{dG}$ ) were pumped into bioreactor digestion system. Then, the enzymatic products were injected into HPLC-MS/MS for analysis of 8-oxodG. The calibration curve was obtained by fitting the peak area ratio of $\gamma^{*} 8$-oxodG/dG (where $\gamma=$ peak area of $\left[{ }^{15} \mathrm{~N}_{5}\right]-\mathrm{dG} /$ peak area of $\left[{ }^{15} \mathrm{~N}_{5}\right]-8$-oxodG) and the concentration of 8 -oxodG $/ 10^{6} \mathrm{dG}$. The levels of 8 -oxodG in DNA samples were expressed as the frequency of 8 -oxodG $/ 10^{6}$ dG.

The accuracy represented by recovery of 8 -oxodG was estimated by spiking 8-oxodG standard at three different concentration levels $(5,20$, and $50 \mathrm{nM})$ into DNA samples before digestion. Recovery $(\%)=[($ the measured - the background)/the added amount $] \times 100 \%$. The intraday and interday precision was estimated by triplicate quantification of 8-oxodG and dG in DNA samples per day for three consecutive days.

Gel Electrophoresis. $0.8 \%$ Agarose gels were used to investigate the pattern and sizes of DNA fragments generated by enzyme digestion for DNase I-bioreactor, and 16\% PAGE gels for the three-enzyme cascade bioreactor. The electro- phoresis was conducted at $1 \times$ TBE buffer containing Tris $(10.8 \mathrm{~g} / \mathrm{L})$, boric acid $(5.5 \mathrm{~g} / \mathrm{L})$, and EDTA $(0.75 \mathrm{~g} / \mathrm{L})$ at 200 $\mathrm{V}$ for $1 \mathrm{~h}$. Then the gels were stained with ethidium bromide solution for $10 \mathrm{~min}$. The fluorescent bands induced by UV light, was recorded on Gel Documentation System.

MALDI-TOF Mass Spectrometry Analysis. MALDI-TOF MS analysis was performed on Bruker Autoflex III smart beam mass spectrometer (Bruker Daltonics, Bremen, Germany). At the mass range of $m / z 100-10000,90 \%-100 \%$ laser energy, 2 $\times 10^{-6}$ mbar vacuum, $200 \mathrm{~Hz}$ trigger frequency, linear positiveion mode and $200 \mathrm{~s}$ extraction delay time was set to get best mass resolution and high sensitivity, and average of 0-200 laser shots was accumulated for each spectrum. Nicotinci acid (NA), Anthranilic acid (AA) and diammonium hydrogen citrate (DHC) were chosen as matrixes, and molar ratio was 2:1:0.006 (NA/AA/DHC). The DNA digestion solution was mixed with matrix solution $(1: 1, \mathrm{v} / \mathrm{v})$ sufficiently and then deposited onto MALDI target plate for airing and crystallization.

\section{RESULTS AND DISCUSSION}

Fabrication and Characterization of DNase I, SVP, and ALPase Bioreactors. The DNase I, SVP, and ALPaseimmobilized bioreactors were fabricated in capillary silica monolith according to our previous work. ${ }^{45}$ In brief, three major steps were included (Scheme 1). First, the silica

Scheme 1. Synthesis of Silica Monoliths and Immobilization of Enzymes in Capillary Monoliths ${ }^{a}$

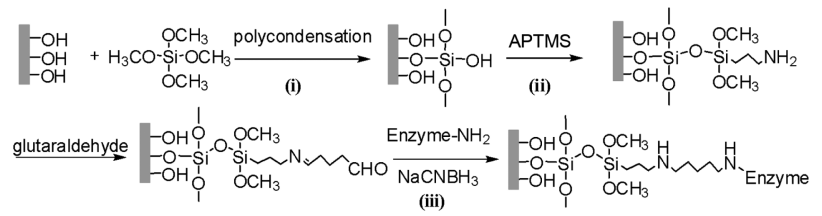

a(i) Preparation of silica monolith in capillary by in situ sol-gel polymerization of TMOS; (ii) introduction of amino groups to the surface of the capillary monolith by APTMS silylation, and (iii) immobilization of enzymes (DNase I, SVP, ALPase) via Shiff-Base reaction using glutaraldehyde to link the amino groups between the modified monolith and enzymes, finally reduction by sodium cyanoborohydride.

monolith was in situ synthesized in a fused-silica capillary (i.d. $75 \mu \mathrm{m}$ ) using the sol-gel polymerization of TMOS. ${ }^{45}$ Then the silylation reagent (3-aminopropyltriethoxysilane) was used to introduce amino groups to the surface of the capillary monolith. Finally, the DNase I, SVP, and ALPase were immobilized onto the monolith via Schiff-Base reaction by using glutaraldehyde to link the $-\mathrm{NH}_{2}$ groups on monolith and enzymes. To enhance the stability of immobilized enzymes, sodium cyanoborohydride was used to reduce the formed $\mathrm{C}=$ $\mathrm{N}$ to stable $\mathrm{C}-\mathrm{N}$ bonds. ${ }^{46}$

The constructed monolith was imaged by scanning electron microscopy (SEM). Capillary silica monolith can provide low back pressure and large surface area because of its high mechanical strength and porous structure. As shown in Figure 1 , the silica monolith has porous structure, which offers high surface area $\left(164 \pm 12 \mathrm{~m}^{2} / \mathrm{g}\right)$ for enzyme immobilization and ensures good permeability $\left(1.27 \times 10^{-13} \mathrm{~m}^{2}\right)$ and low backpressure. Benefiting from this merit, ct-DNA $(5-30 \mathrm{~Kb}$ measured in Figure 2c) solution can be passed through the capillary bioreactors by hand pushing or a low pressure microinjection pump. 
a)

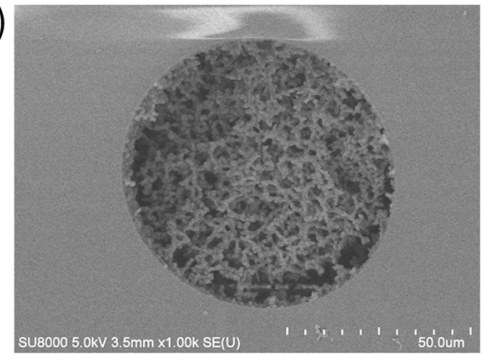

c) DNase I
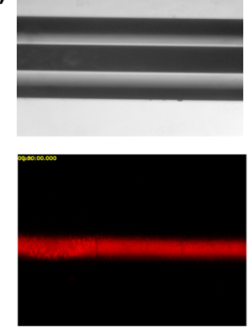

d) SVP

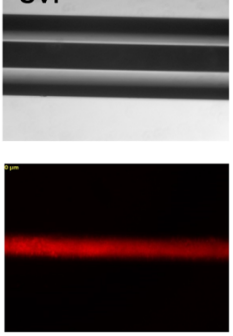

b) Bare silica monolith

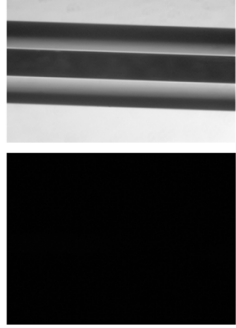

e) ALPase

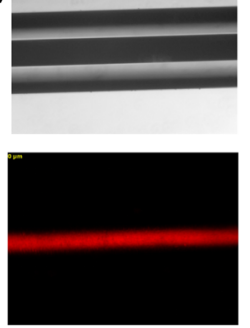

Figure 1. Characterization of DNase I, SVP, and ALPase-immobilized bioreactors. (a) Scanning electron microscopic image of the porous silica monolith within the capillary bioreactors. Bright field (the upper rows) and fluorescence images of (b) the capillary silica monolith, (c) the DNase I-immobilized, (d) the SVP-immobilized, and (e) the ALPase-immobilized bioreactors. The capillaries were stained with SYPRO orange dye (1:5000) for $15 \mathrm{~min}$ and then rinsed with $20 \mathrm{mM}$ Tris- $\mathrm{HCl}$ buffer for $10 \mathrm{~min}$ to remove the unbound dyes prior to imaging.

a)

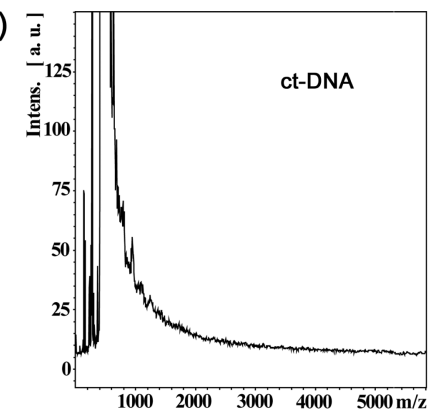

c)

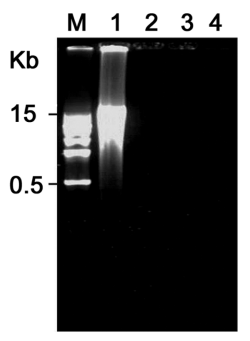

b)

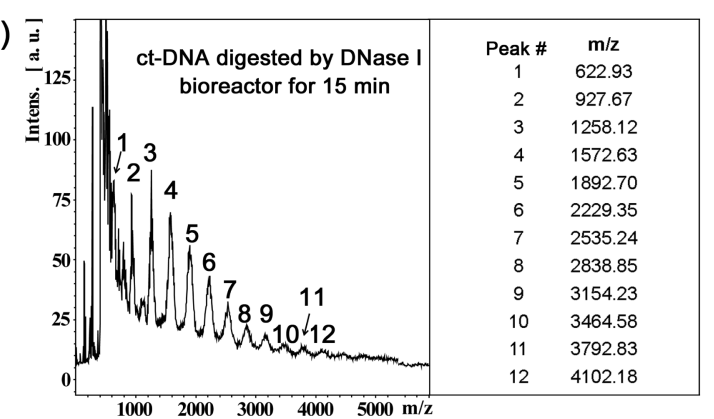

Figure 2. Digestive performance of DNase I-immobilized bioreactor. (a) MALDI-TOF MS analysis of the pristine ct-DNA, (b) MALDITOF MS analysis of the products ct-DNA digested by DNase I bioreactor (15 $\mathrm{min})$, and (c) the agarose gel electrophoresis (AGE) image of ct-DNA (lane 1) and its digested products adopted at 15 (lane 2), 30 (lane 3), and $45 \mathrm{~min}$ (lane 4).

To examine whether enzymes had immobilized on the monolith, SYPRO orange dye was used to stain the enzymes and detected by fluorescence inverted microscope with blue light $(450-490 \mathrm{~nm})$. As can be seen in Figure 1a, DNase I,

SVP, and ALPase immobilized monoliths show obvious fluorescence compared with monolith without enzyme immobilization, and enzymes were evenly distributed in the monoliths.

Construction of the Cascade Capillary Bioreactor. The cascade bioreactors were assembled by tandem connecting the enzyme-immobilized capillary microreactors in an order of DNase I-SVP-ALPase with zero-volume steel unions. Being different from solution digestion that three hydrolytic enzymes were mixed together, the connection sequence of DNase I, SVP, and ALPase bioreactors has influences on the digestion performance. Removal of SVP bioreactor or put it in front of DNase I bioreactor will deteriorate the digestion efficiency to $59.8-83.7 \%$. For instance, ranging the bioreactors in an order of SVP-DNase I-ALPase led to a decreased enzymatic efficiency of $83.7 \pm 1.0 \%$. This is probably because that both of DNase I and SVP are capable of generating mononucleotides and oligonuclesides, but DNase I tends to digest double-strands DNA to generate small DNA fragments (2-10 nucleotides) whereas SVP bioreactor seems more efficient on enzymatic hydrolysis of oligonucleotides to release mononucleotides. ${ }^{20,37}$ Thus, the connection sequence of DNase I-SVP-ALPase ensures high efficiency for genomic DNA digestion.

Fast Digestion of Genomic DNA into Single Nucleosides. To verify the cleavage of ct-DNA by DNase I bioreactor, $500 \mathrm{ng} / \mu \mathrm{L}$ of ct-DNA was pumped into this bioreactor and incubated for 15,30 , and $45 \mathrm{~min}$, then the digestion products were pumped out and resolved by $0.8 \%$ agarose gel. A diffused band with the size of $5-30 \mathrm{~Kb}$ appears in the gel, which refers to the pristine ct-DNA was used as the control. No distinct bands can be seen after the digestion process for 15,30 , and 45 $\min$ (Figure 2c). We speculated that ct-DNA has been digested to small DNA fragments (less than $0.1 \mathrm{~Kb}$ ) due to the highly enzymatic performance of DNase I bioreactor.

To verify the above speculation, we then analyzed the digestion products at $15 \mathrm{~min}$ by MALDI-TOF mass spectrometry to identify DNA fragments. As shown in Figure 2a, there are no signals of small DNA fragments of ct-DNA were found from $m / z=900$ to 4000 . On the contrary, by application of DNase I bioreactor, mass ladder was generated from $m / z=600$ to 4000 with the digestion sample at adopted $15 \mathrm{~min}$ (Figure $2 \mathrm{~b}$ ), which suggested that ct-DNA can be digest to mononucleotides $(\sim 90 \%)$ and small oligonucleotides $(\sim 10 \%)$.

Similarly, the enzymatic performance of SVP bioreactor was tested by using a 20-mer oligodeoxynucleotides probe $\left(5^{\prime}\right.$ CCCATTACCAGCCAGCTAAT-3'). An aliquot of $500 \mathrm{ng} /$ $\mu \mathrm{L}$ 20-mer oligonucleotides was pumped into the SVP bioreactor and incubated for $5 \mathrm{~min}$. The enzymatic digestion products of 20-mer oligodeoxynucleotides were then examined by MALDI-TOF mass spectrometry (Figure 3). A series of desired mass ladders detected by MALDI-TOF mass spectrometry ensures that the SVP bioreactor can be applied to release mononucleotides from 3 '-hydrox-terminated oligonucleotides. This result is well in accordance with obviations of our previous study. ${ }^{45}$

Then the enzymatic efficiency of three-enzyme cascade bioreactor was evaluated. To this purpose, $12 \mu \mathrm{L}$ of $200 \mathrm{ng} / \mu \mathrm{L}$ ct-DNA was pumped through the cascade bioreactor and digested for 5,10 , and $15 \mathrm{~min}$, respectively, until $60 \mu \mathrm{L}$ of products were collected. The digestion products were analyzed by $16 \%$ PAGE gel for evaluation of enzymatic performance of the cascade bioreactor (Figure 4a). By application of 3-enzyme 
a)

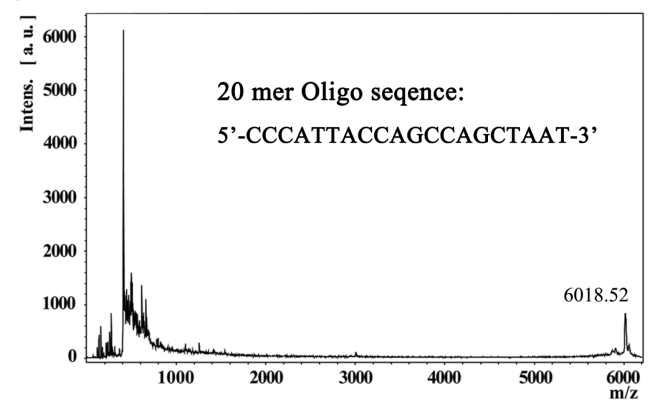

b)

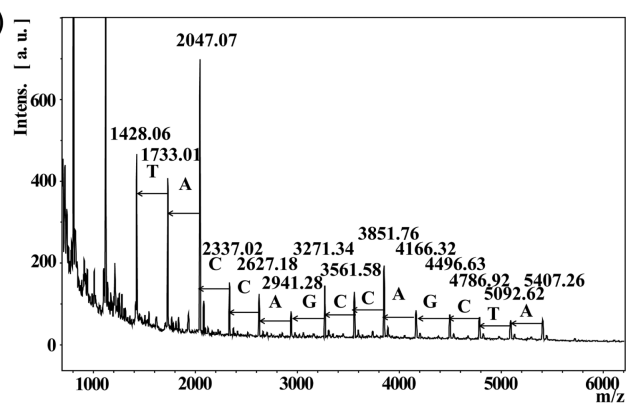

Figure 3. Digestive performance of SVP-immobilized bioreactor. (a) MALDI-TOF MS analysis of 20-mer oligodeoxynucleotides (5'CCCATTACCAGCCAGCTAAT-3') which shows a molecular weight of $6018.5 \mathrm{Da}$; (b) MALDI-TOF MS analysis of the mass ladder generated from the digestion of 20-mer oligo $(5 \mathrm{~min})$.

a)
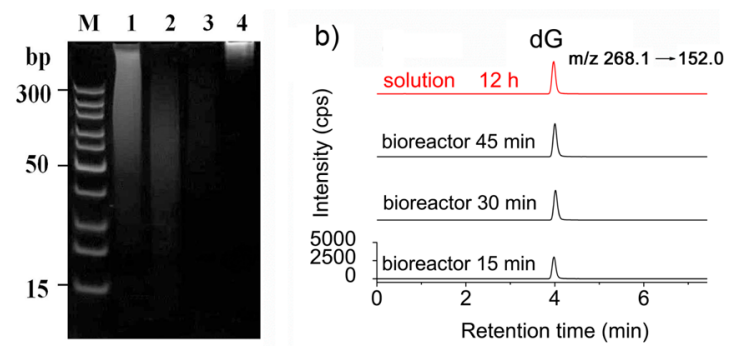

c)

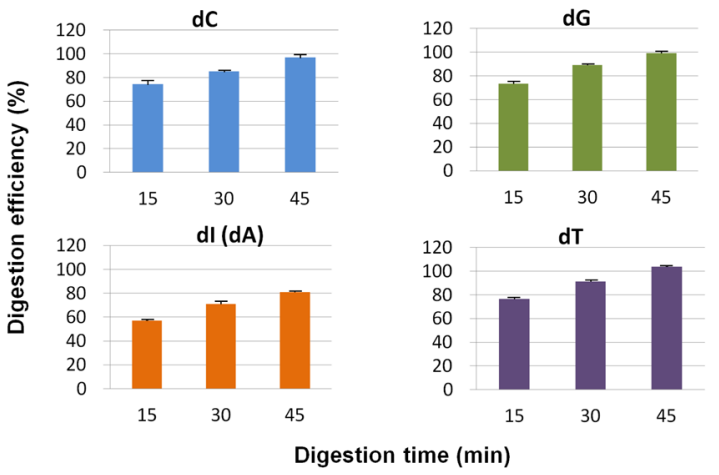

Figure 4. Digestion efficiency of the cascade bioreactor for enzymatic hydrolysis of ct-DNA. (a) PAGE images of ct-DNA (lane 4) and its cleavage products after incubated in the cascade bioreactor for 5 (lane 1), 10 (lane 2), and $15 \mathrm{~min}$ (lane 3). (b) HPLC-MS/MS analysis of $\mathrm{dG}$ in cleavage products generated from the cascade bioreactor digestion for 15, 30, and 45 min (black trace) and from free solution digestion (red trace, $24 \mathrm{~h}$ ). (c) Digestion efficiency of the cascade bioreactor for enzymatic hydrolysis of ct-DNA, in terms of the production of $\mathrm{dC}, \mathrm{dG}, \mathrm{dT}$, and $\mathrm{dI}$ nucleosides $(n=3)$.

cascade bioreactor, ct-DNA strands were digested rapidly and small-size fragments less than $300 \mathrm{bp}$ were produced within 10 min (lane 2). From PAGE image, no DNA strip can be found thus it seems almost the total ct-DNA strands have been degraded into nucleosides within $15 \mathrm{~min}$ (line 3). Incubating ct-DNA in the bioreactor for longer time 30 and $45 \mathrm{~min}$, the products were applied to PAGE analysis and showed no DNA strip in the gel.

HPLC-MS/MS analysis provided more sensitive and accurate results. To investigate the digestion efficiency of the cascade bioreactor, the collected digestive products of ct-DNA at incubation time of 15,30 , and $45 \mathrm{~min}$ were injected into HPLC-MS/MS for quantitative analysis of nucleosides. The enzymatic digestion efficiency (\%) was calculated according to the measured nucleosides being divided by theoretical calculated nucleosides. As can be seen from Figure 3c, the enzymatic digestion efficiency at $15 \mathrm{~min}$ ranges from 73.4 to $76.8 \%$ for $\mathrm{dC}, \mathrm{dG}$, and $\mathrm{dT}$, while it can reach $97.1 \pm 2.4 \%$ for $\mathrm{dC}, 99.3 \pm 1.6 \%$ for $\mathrm{dG}$, and $103.7 \pm 0.8 \%$ for $\mathrm{dT}$ with digestion of $45 \mathrm{~min}$ (Figure 4c). dA was not considered in our calculation because it has been converted to $\mathrm{dI}(>80 \%)$ by adenosine deaminase which was an impurity contaminants in ALPase. This finding is in accordance with what has been reported. ${ }^{10}$ The above results demonstrate that the cascade bioreactor can be used to digest genomic DNA and release nucleosides effectively at short time less than $1 \mathrm{~h}$. In this experiment, the nucleoside $\mathrm{dG}$ was selected as the marker to evaluate the digestion efficiency of enzymes under different digestion conditions. A representative chromatogram of dG by HPLC-MS/MS analysis is shown in Figure $4 \mathrm{~b}$.

The digestion reaction also conducted in solution, the routinely used condition in our laboratory. Enzymes including 1 $\mathrm{U}$ of DNase I, $1 \mathrm{U}$ of SVP, and $0.5 \mathrm{U}$ of ALPase were added to $50 \mu \mathrm{L}$ of $200 \mathrm{ng} / \mu \mathrm{L}$ ct-DNA solution system at $37{ }^{\circ} \mathrm{C}$. The digestion efficiency reached $93.0 \pm 1.6 \%$ until $6 \mathrm{~h}$ in solution enzymatic system (Figure S1), whereas a higher enzymatic efficiency $(99.3 \pm 1.6 \%)$ could be obtained within 45 min by using the three-enzyme cascade bioreactor. To achieve digestion efficiency near $100 \%$, the solution system needs another 2-6 h digestive reaction. This result indicates that 3enzyme cascade bioreactor is more efficient than traditional solution digestion process in respect of DNA digestion.

The application of three-enzyme cascade bioreactor in genomic DNA digestion provides a higher digestion rate than that of enzymes solution. Although digesting the genomic DNA into mononucleotides has digestive rates varied from ten to several hundreds of base pairs per second $(\mathrm{bp} / \mathrm{s}),{ }^{47-50}$ the digestive rate into single nucleosides seems much lower. Given the average size of ct-DNA is $20 \mathrm{~Kb}(5-30 \mathrm{~Kb}$ measured by AGE) and digesting ct-DNA into nucleosides completely requires $8 \mathrm{~h}$, the average digestive rate of ct-DNA (into nucleosides) in solution is estimated at $0.5 \mathrm{bp} / \mathrm{s}$. However, it is enhanced to approximately $10 \mathrm{bp} / \mathrm{s}$ using the cascade bioreactor. The increase of enzymatic efficiency and digestive rate are probably attributed to the high local concentration of enzymes in the cascade bioreactor and enhanced stability.

Enzymatic Activities of the Cascade Bioreactors. The immobilized capacity and enzyme activity of DNase I, SVP, and ALPase were investigated and result are listed in Table S1. The capacity of enzyme was determined based on Bradford assay. DNase I, SVP, and ALPase bioreactor were incubated with 0.1 $\mathrm{M}$ of $\mathrm{NaOH}$ for $2 \mathrm{~h}$ to release enzyme from the bioreactors. Then, the enzyme solution was pumped out of monolith and mixed with $500 \mu \mathrm{L}$ of Bradford reagent. After incubated at room temperature for $5 \mathrm{~min}$, the absorbance of $595 \mathrm{~nm}$ was 
measured by microplate reader. The amount of immobilized enzyme was calculated by standard curve. Result exhibits that the immobilized enzyme is about $1.15 \mathrm{mg} / \mathrm{mL}$ for DNase I, $1.27 \mathrm{mg} / \mathrm{mL}$ for SVP, and $1.48 \mathrm{mg} / \mathrm{mL}$ for ALPase respectively, showing high immobilization capacity (Table 1). Correspondingly, the bound amount of each enzyme was $0.91 \mu \mathrm{g}$ for DNase I $(20 \mathrm{~cm}), 0.75 \mu \mathrm{g}$ for SVP $(15 \mathrm{~cm})$, and $0.87 \mu \mathrm{g}$ for ALPase $(15 \mathrm{~cm})$ bioreactors.

Table 1. Immobilization Capacity and Enzyme Activity of the Immobilized Enzymes in the Cascade Bioreactor and Free Enzymes in Solution System ${ }^{a}$

\begin{tabular}{lccc} 
& & \multicolumn{2}{c}{$\begin{array}{c}\text { enzymatic activity } \\
(\mathrm{U} / \mathrm{mL})\end{array}$} \\
\cline { 3 - 4 } & immobilization capacity $(\mathrm{mg} / \mathrm{mL})$ & bioreactor & solution \\
DNase I & 1.15 & 1117 & 130 \\
PDE & 1.27 & 0.022 & 0.007 \\
ALPase & 1.48 & 4.210 & 0.062
\end{tabular}

${ }^{a}$ The activity of immobilized and free enzymes was measured with UV-vis spectrophotometry. More details are described in the Supporting Information.

DNase I activity was determined by monitoring the increasing absorbance at $260 \mathrm{~nm}\left(A_{260}\right)$ and SVP; ALPase activity were estimated by measuring the absorbance at $400 \mathrm{~nm}$ (Supporting Information). The enzymatic activity in the cascade bioreactor is $1117 \mathrm{U} / \mathrm{mL}$ for DNase I, $0.023 \mathrm{U} / \mathrm{mL}$ for SVP, and $4.20 \mathrm{U} / \mathrm{mL}$ for ALPase, whereas it is $130,0.007$, and $0.06 \mathrm{U} / \mathrm{mL}$ for DNase I, SVP, and ALPase in solution condition, respectively. In a word, compared to the enzymes in free solution condition, immobilized enzymes in bioreactor enhanced the enzymatic activity by 9-fold for DNase I, 3-fold for SVP, and 70-fold for ALPase, respectively. The high activity together with the high capacity of the immobilized enzymes enables the fast and complete digestion of ct-DNA into nucleosides within $45 \mathrm{~min}$.

Reproducibility and Reusability of the Cascade Bioreactors. The reproducibility of bioreactor was studied by using ct-DNA as the substrate, and dG was detected to characterize the DNA digestion efficiency. Result shows that RSD for enzyme activity by batch-to-batch analysis was 3.9\% ( $n$ $=3$ ) and run-to-run analysis was $6.6 \%(n=3)$, which proved that the reproducibility of the silica monolith based bioreactor is acceptable for the routine analysis.

The longevity of the bioreactor was investigated by storing it in $10 \mathrm{mM}$ Tris- $\mathrm{HCl}$ buffer ( $\mathrm{pH} 7.4,0.05 \% \mathrm{BSA}, 0.02 \% \mathrm{NaN}_{3}$ ) at $4{ }^{\circ} \mathrm{C}$. The monolith was not destroyed during the repeated measurement. In addition, there was less than $20 \%$ variation of enzyme activity after bioreactor was used for 20 times or stored at $4{ }^{\circ} \mathrm{C}$ for 30 days (Figure 5). However, a mixture solution of DNase I, SVP, and ALPase, which were stored at same condition, almost completely lost its activity within 1 day. The result indicated that stability of enzymes was greatly enhanced after immobilized on the silica matrix because the matrix could prevent autolysis of the enzyme effectively. That means the cascade bioreactor possesses a unique superiority in stability and reutilization.

Development of the Cascade Bioreactor Off-line Coupled HPLC-MS/MS Method for 8-oxodG Detection. By advantage of the cascade bioreactor, we further developed an immobilized enzymes-based DNA digestion coupled UHPLC-MS method for fast screening of the oxidative stress a)

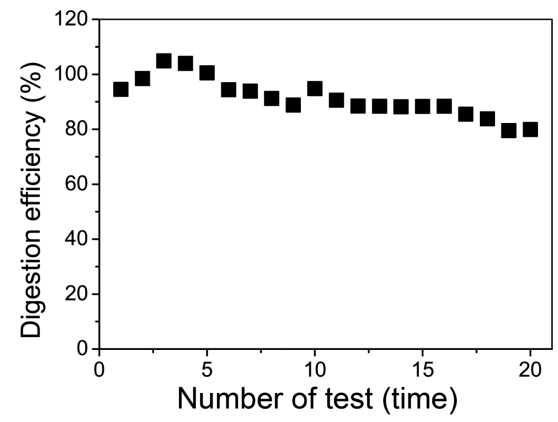

b)

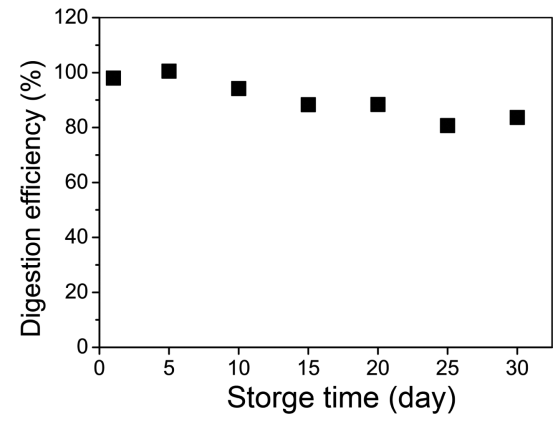

Figure 5. Stability of the cascade bioreactor. (A) Variation of digestion efficiency during bioreactor was used for 20 times. (B) Variation of digestion efficiency during bioreactor was stored at $4{ }^{\circ} \mathrm{C}$ for 30 days. Digestion efficiency was measured using $\mathrm{dG}$ as the marker.

marker 8-oxodG in genomic DNA. Oxidative DNA damage has been supposed to be closely associated with the occurrence of cancer and degenerative diseases. ${ }^{51-54}$ 8-Oxo-7,8-dihydro- 2 'deoxyguanosine (8-oxodG) as a stable biomarker of oxidative DNA damage products has been extensively detected in human tissues, blood and urine. ${ }^{21-23}$

In this experiment, multiple reaction monitoring (MRM) mode was adopted for selective detection of 8-oxodG $(\mathrm{m} / z$ $284.1 \rightarrow 168.0)$ and $\left[{ }^{15} \mathrm{~N}_{5}\right]$-8-oxodG $(289.1 \rightarrow 173.0)$. The untreated $\mathrm{dG}$ was chosen as internal standard in order to calibrate the deviations of sample preparation and monitored by transition ion of $m / z 268.1 \rightarrow 152.0$, and $\left[{ }^{15} \mathrm{~N}_{5}\right]-\mathrm{dG} 273.1$ $\rightarrow$ 157.0. The linear equation for 8-oxodG was obtained as $y=$ $0.0019 x+0.0848\left(R^{2}=0.998\right)$, presenting a good linear correlation of signal response of $\gamma^{*} 8$-oxodG/dG with the concentration 8-oxodG $/ 10^{6} \mathrm{dG}$. This result revealed that 8oxodG in genomic DNA could be released effectively by using cascade bioreactor. The linear equation can be used to calculated concentration of 8-oxodG in DNA samples digested in bioreactor.

The limit of detection (LOD, $/ N \geq 3$ ) was $0.3 \mathrm{nM}$ and limit of quantification (LOQ) was $1.0 \mathrm{nM}$ for 8-oxodG. The recovery was measured by spiking DNA samples with three concentration levels $(5,20$, and $50 \mathrm{nM})$ of 8 -oxodG. The estimated recovery is about $109.4 \pm 4.9 \%$ for $5 \mathrm{nM}$ 8-oxodG, $95.4 \pm 7.4 \%$ for $20 \mathrm{nM} 8$-oxodG, and $84.5 \pm 1.0 \%$ for $50 \mathrm{nM} 8$ oxodG, respectively. The precision of this method was evaluated by performing replicate determination of 8 -oxodG in DNA sample treated by Fenton reaction. The intraday precision for 8-oxodG was $2.1 \%(n=5)$ and interday precision was $7.2 \%(n=3)$, respectively.

Screening of 8-oxodG in ct-DNA Induced by Fenton Reaction. We further demonstrated the applicability of the cascade bioreactor to determine DNA damages in genomic DNA using 8-oxodG as an example. Transition metals $\mathrm{Fe}^{2+}$ and 
$\mathrm{Cu}^{+}$can react with $\mathrm{H}_{2} \mathrm{O}_{2}$ via Fenton reaction to generate ROS, which is associated with 8-oxodG formation in DNA. ${ }^{55,56}$ In this experiment, $200 \mathrm{ng} / \mu \mathrm{L}$ of ct-DNA $(120 \mu \mathrm{L})$ were reacted with $10 \mu \mathrm{M} \mathrm{Fe}^{2+}$ and $50 \mu \mathrm{M} \mathrm{H}_{2} \mathrm{O}_{2}$ at $37^{\circ} \mathrm{C}$ for $2 \mathrm{~h}$. Aliquot of $12 \mu \mathrm{L}$ of the resultant products $(2.4 \mu \mathrm{g}$ ct-DNA were subjected to the cascade bioreactor for enzymatic digestion and thereafter HPLC-MS detection. As a contrast, these samples were also digested in free solution conditions. Figure 6a shows MRM
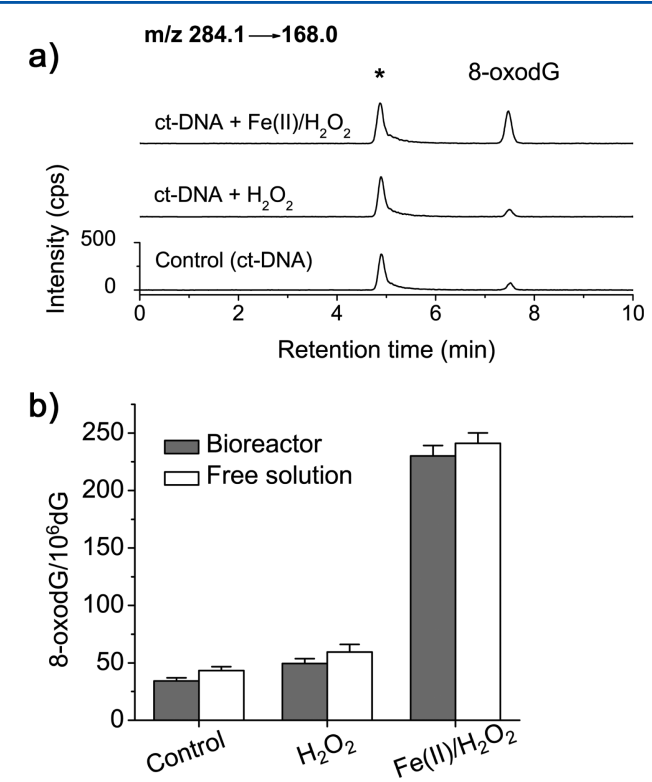

Figure 6. (a) HPLC-MS/MS analysis of 8-oxodG in ct-DNA induced by $\mathrm{H}_{2} \mathrm{O}_{2}$ and $\mathrm{Fe}(\mathrm{II}) / \mathrm{H}_{2} \mathrm{O}_{2}$ using the cascade bioreactor for DNA digestion (* refers to oxidized dG in ESI source); (b) comparison of the frequency of 8 -oxodG between the cascade bioreactor and free enzymatic digestion protocols $(n=3)$.

chromatogram of 8-oxodG in ct-DNA induced by $\mathrm{H}_{2} \mathrm{O}_{2}$ and $\mathrm{Fe}(\mathrm{II}) / \mathrm{H}_{2} \mathrm{O}_{2}$ treatment using HPLC-MS/MS. The analysis of 8 -oxodG could be accomplished within $8 \mathrm{~min}$. Together with the digestion process in cascade bioreactor $(15-45 \mathrm{~min})$, the time for a single run was less than $1 \mathrm{~h}$. This is more timeresaving than that of solution digestion coupled HPLC-MS/MS protocols $(8-12 \mathrm{~h})$. By application of the cascade bioreactor coupled LC-MS/MS, only a minute of ct-DNA samples (2.4 $\mu \mathrm{g}$ ) were required for a single run of HPLC-MS/MS analysis. Moreover, the frequency of 8-oxodG was measured as 34.3 lesions $/ 10^{6} \mathrm{dG}$ in pristine ct-DNA, 49.5 lesions $/ 10^{6} \mathrm{dG}$ in $\mathrm{H}_{2} \mathrm{O}_{2}$ treated ct-DNA, and 230.1 lesions $/ 10^{6} \mathrm{dG}$ in $\mathrm{Fe}(\mathrm{II}) /$ $\mathrm{H}_{2} \mathrm{O}_{2}$ treated ct-DNA. It seems somewhat lower than that obtained by solution enzymatic digestion protocol, which is 43.3, 59.5, and 241.1 lesions $/ 10^{6} \mathrm{dG}$ for pristine, $\mathrm{H}_{2} \mathrm{O}_{2}$, and $\mathrm{Fe}(\mathrm{II}) / \mathrm{H}_{2} \mathrm{O}_{2}$ treated ct-DNA respectively. This is probably because the application of the cascade bioreactor decreases artificial interferences toward 8-oxodG detection in virtue of the short digestion time, anoxic condition in bioreactor and free of heat denatures of enzymes, ultrafiltration and solid-phase extraction. In a word, our results suggest that the cascade bioreactor works well on complete digestion of DNA (no less than $99.3 \%$ ) and releasing of 8-oxodG, which is important for accurate quantification of 8-oxodG in genomic DNA.

The cascade bioreactor was also applied to larger genomic DNA $(20-100 \mathrm{~Kb})$ isolated from the cultured HepG2 (hepatic cell line) and T24 (bladder cancer) cells, showing a digestive efficiency was more than $99.0 \%$. Result shows that 8 -oxodG in
HepG2 and T24 cells are in a range of $2.2-11.3$ lesions $/ 10^{6}$ dG.

\section{CONCLUSION}

A novel cascade capillary monolithic bioreactor dedicated to genome DNA digestion was developed via jointing DNase I, SVP, and ALPase immobilized bioreactor together in sequence. Benefiting from high capacity and enzymatic activity of immobilized enzymes, the cascade bioreactor exhibits excellent digestion efficiency ( $\sim 99.3 \%)$ when DNA samples pass through the bioreactor for $45 \mathrm{~min}$, which is conductive to rapid release of nucleosides and reduce artificial addition of 8-oxodG. By taking advantages of its good permeability and mechanical strength, DNA samples can be injected into bioreactor easily by a low-pressure microinjection pump without destroying the structure of the cascade bioreactor. The collected product could be directly injected into HPLC-MS/MS without tedious ultrafiltration process. In addition, the remarkable stability of the immobilized enzymes guarantees the reusability and longtime preservation of the cascade bioreactor. By the advantages of the cascade bioreactor, 8-oxodG induced by $\mathrm{Fe}(\mathrm{II}) / \mathrm{H}_{2} \mathrm{O}_{2}$ was accurately detected in ct-DNA. Our work demonstrated that the cascade monolithic bioreactor was powerful for HPLC-MS/MS analysis of 8-oxodG and are promising in rapid identification and highly sensitive detection of adducts in genomic DNA samples.

\section{ASSOCIATED CONTENT}

\section{Supporting Information}

The Supporting Information is available free of charge on the ACS Publications website at DOI: 10.1021/acs.analchem.6b01682.

DNase I activity assay, SVP activity assay, ALPase activity assay, HPLC-MS/MS analysis of the cleavage products, and digestion efficiency of ct-DNA (PDF)

\section{AUTHOR INFORMATION}

\section{Corresponding Author}

*E-mail: hlwang@rcees.ac.cn. Phone and Fax: +86-1062849600 .

\section{Notes}

The authors declare no competing financial interest.

\section{ACKNOWLEDGMENTS}

This work was supported by grants from the Ministry of Science and Technology of China (2016YFC0900301 and 2011YQ060084), the National Natural Science Foundation of China (21375142, 21321004, and 21435008), and the Strategic Priority Research Program of the Chinese Academy of Sciences (XDB14030300 and XDB14030200). H. Wang dedicates this work to the memory of his Ph.D. mentor, Dr. Hanfa Zou, of the Dalian Institute of Chemical Physics, Chinese Academy of Sciences, who passed away on April 25, 2016. Dr. Zou was a distinguished professor who made outstanding contributions in the field of liquid phase-based separation and the methodologies and technologies for the study of proteomics. He was also a talented and highly respected mentor having trained and enlightened over 100 graduate students.

\section{REFERENCES}

(1) Farmer, P. B.; Singh, R. Mutat. Res., Rev. Mutat. Res. 2008, 659, 68-76. 
(2) Klapacz, J.; Pottenger, L. H.; Engelward, B. P.; Heinen, C. D.; Johnson, G. E.; Clewell, R. A.; Carmichael, P. L.; Adeleye, Y.; Andersen, M. E. Mutat. Res., Rev. Mutat. Res. 2016, 767, 77-91.

(3) Grigoryeva, E. S.; Kokova, D. A.; Gratchev, A. N.; Cherdyntsev, E. S.; Buldakov, M. A.; Kzhyshkowska, J. G.; Cherdyntseva, N. V. Exp. Oncol. 2015, 37, 5-12.

(4) O'Connor, M. J. Mol. Cell 2015, 60, 547-560.

(5) Tretyakova, N.; Villalta, P. W.; Kotapati, S. Chem. Rev. 2013, 113, 2395-2436.

(6) Wauchope, O. R.; Beavers, W. N.; Galligan, J. J.; Mitchener, M. M.; Kingsley, P. J.; Marnett, L. J. Chem. Res. Toxicol. 2015, 28, 23342342 .

(7) Chango, A.; Abdel Nour, A. M.; Niquet, C.; Tessier, F. J. Med. Princ. Pract. 2009, 18, 81-84.

(8) Noberini, R.; Sigismondo, G.; Bonaldi, T. Epigenomics 2016, 8, 429-445.

(9) Liu, S.; Wang, Y. Chem. Soc. Rev. 2015, 44, 7829-7854.

(10) Schumacher, F.; Herrmann, K.; Florian, S.; Engst, W.; Glatt, H. Anal. Biochem. 2013, 434, 4-11.

(11) Farmer, P. B.; Brown, K.; Tompkins, E.; Emms, V. L.; Jones, D. J.; Singh, R.; Phillips, D. H. Toxicol. Appl. Pharmacol. 2005, 207, 293301.

(12) Andrews, C. L.; Vouros, P.; Harsch, A. J. Chromatogr. A 1999, $856,515-526$.

(13) Stornetta, A.; Villalta, P. W.; Hecht, S. S.; Sturla, S. J.; Balbo, S. Anal. Chem. 2015, 87, 11706-11713.

(14) Xu, F. F.; Yang, T.; Chen, Y. Anal. Chem. 2016, 88, 754-763.

(15) Anders, N. M.; Liu, J.; Wanjiku, T.; Giovinazzo, H.; Zhou, J.; Vaghasia, A.; Nelson, W. G.; Yegnasubramanian, S.; Rudek, M. A. J. Chromatogr. B: Anal. Technol. Biomed. Life Sci. 2016, 1022, 38-54.

(16) Yin, R. C.; Mo, J. Z.; Lu, M. L.; Wang, H. L. Anal. Chem. 2015, 87, 1846-1852.

(17) Yin, R. C.; Mao, S. Q.; Zhao, B. L.; Chong, Z. C.; Yang, Y.; Zhao, C.; Zhang, D. P.; Huang, H.; Gao, J.; Li, Z.; Jiao, Y.; Li, C. P.; Liu, S. Q.; Wu, D. N.; Gu, W. K.; Yang, Y. G.; Xu, G. L.; Wang, H. L. J. Am. Chem. Soc. 2013, 135, 10396-10403.

(18) Wang, X. L.; Suo, Y. S.; Yin, R. C.; Shen, H. Q.; Wang, H. L. J. Chromatogr. B: Anal. Technol. Biomed. Life Sci. 2011, 879, 1647-1652.

(19) Zhang, G.; Huang, H.; Liu, D.; Cheng, Y.; Liu, X.; Zhang, W.; Yin, R.; Zhang, D.; Zhang, P.; Liu, J.; Li, C.; Liu, B.; Luo, Y.; Zhu, Y.; Zhang, N.; He, S.; He, C.; Wang, H.; Chen, D. Cell 2015, 161, 893906.

(20) Huang, X.; Powell, J.; Mooney, L. A.; Li, C. L.; Frenkel, K. Free Radical Biol. Med. 2001, 31, 1341-1351.

(21) Yin, R. C.; Zhang, D. P.; Song, Y. L.; Zhu, B. Z.; Wang, H. L. Sci. Rep. 2013, 3, 1269.

(22) Yamashita, N.; Tanemura, H.; Kawanishi, S. Mutat. Res., Fundam. Mol. Mech. Mutagen. 1999, 425, 107-115.

(23) Hosozumi, C.; Toriba, A.; Chuesaard, T.; Kameda, T.; Tang, N.; Hayakawa, K. J. Chromatogr. B: Anal. Technol. Biomed. Life Sci. 2012, 893, 173-176.

(24) Serdar, M.; Sertoglu, E.; Uyanik, M.; Tapan, S.; Akin, K.; Bilgi, C.; Kurt, I. Free Radical Res. 2012, 46, 1291-1295.

(25) Liou, S. H.; Chen, Y. C.; Liao, H. Y.; Wang, C. J.; Chen, J. S.; Lee, H. L. Biomarkers 2016, 1.

(26) Fan, Y. Y.; Neubert, H. Anal. Chem. 2016, 88, 4239-4247.

(27) Wu, F.; Zhao, M.; Zhang, Y.; Su, N.; Xiong, Z.; Xu, P. Rapid Commun. Mass Spectrom. 2016, 30, 1059-1066.

(28) Jiang, S.; Zhang, Z.; Li, L. J. Chromatogr. A 2015, 1412, 75-81. (29) Foo, H. C.; Smith, N. W.; Stanley, S. M. Talanta 2015, 135, 1822.

(30) Lin, L. H.; Liu, S. Q.; Nie, Z.; Chen, Y. Z.; Lei, C. Y.; Wang, Z.; Yin, C.; Hu, H. P.; Huang, Y.; Yao, S. Z. Anal. Chem. 2015, 87, 45524559.

(31) Liu, J.; Wang, F.; Lin, H.; Zhu, J.; Bian, Y.; Cheng, K.; Zou, H. Anal. Chem. 2013, 85, 2847-2852.

(32) Ma, J.; Liu, J.; Sun, L.; Gao, L.; Liang, Z.; Zhang, L.; Zhang, Y. Anal. Chem. 2009, 81, 6534-6540.
(33) Gillardeaux, O.; Perinroussel, O.; Nocentini, S.; Perin, F. Carcinogenesis 1994, 15, 89-93.

(34) Shimelis, O.; Giese, R. W. J. Chromatogr. A 2006, 1117, 132136.

(35) Jaruga, P.; Theruvathu, J.; Dizdaroglu, M.; Brooks, P. J. Nucleic Acids Res. 2004, 32, e87.

(36) Quinlivan, E. P.; Gregory, J. F., III Anal. Biochem. 2008, 373, $383-385$.

(37) Liao, Q.; Chiu, N. H. L.; Shen, C.; Chen, Y.; Vouros, P. Anal. Chem. 2007, 79, 1907-1917.

(38) Zhang, Z.; Sun, L.; Zhu, G.; Cox, O. F.; Huber, P. W.; Dovichi, N. J. Anal. Chem. 2016, 88, 877-882.

(39) Sun, L.; Zhu, G.; Dovichi, N. J. Anal. Chem. 2013, 85, 41874194.

(40) Xiao, P.; Lv, X.; Wang, S.; Iqbal, J.; Qing, H.; Li, Q.; Deng, Y. Anal. Biochem. 2013, 441, 123-132.

(41) Yuan, H.; Zhang, L.; Hou, C.; Zhu, G.; Tao, D.; Liang, Z.; Zhang, Y. Anal. Chem. 2009, 81, 8708-8714.

(42) Chen, Y.; Wu, M.; Wang, K.; Chen, B.; Yao, S.; Zou, H.; Nie, L. J. Chromatogr. A 2011, 1218, 7982-7988.

(43) Ma, J. F.; Zhang, L. H.; Liang, Z.; Zhang, W. B.; Zhang, Y. K. Anal. Chim. Acta 2009, 632, 1-8.

(44) Sun, L.; Ma, J.; Qiao, X.; Liang, Y.; Zhu, G.; Shan, Y.; Liang, Z.; Zhang, L.; Zhang, Y. Anal. Chem. 2010, 82, 2574-2579.

(45) Zhao, C.; Yin, R.; Yin, J.; Zhang, D.; Wang, H. Anal. Chem. 2012, 84, 1157-1164.

(46) Yin, J.; Song, Y.; Wang, Z.; Wang, H. Electrophoresis 2009, 30, $1362-1371$.

(47) van Oijen, A. M.; Blainey, P. C.; Crampton, D. J.; Richardson, C. C.; Ellenberger, T.; Xie, X. S. Science 2003, 301, 1235-1238.

(48) Kurita, H.; Inaishi, K.-i.; Torii, K.; Urisu, M.; Nakano, M.; Katsura, S.; Mizuno, A. J. Biomol. Struct. Dyn. 2008, 25, 473-480.

(49) Little, J. W.; Lehman, I. R.; Kaiser, A. D. J. Biol. Chem. 1967, 242, 672-678.

(50) Gueroult, M.; Picot, D.; Abi-Ghanem, J.; Hartmann, B.; Baaden, M. PLoS Comput. Biol. 2010, 6, e1001000.

(51) Cooke, M. S.; Olinski, R.; Evans, M. D. Clin. Chim. Acta 2006, $365,30-49$.

(52) Azqueta, A.; Shaposhnikov, S.; Collins, A. R. Mutat. Res., Genet. Toxicol. Environ. Mutagen. 2009, 674, 101-108.

(53) Olinski, R.; Gackowski, D.; Foksinski, M.; Rozalski, R.; Roszkowski, K.; Jaruga, P. Free Radical Biol. Med. 2002, 33, 192-200.

(54) Lohr, M.; Jensen, A.; Eriksen, L.; Gronbaek, M.; Loft, S.; M?ller, P. Oncotarget 2015, 6, 2641-2653.

(55) Imlay, J. A.; Chin, S. M.; Linn, S. Science 1988, 240, 640-642.

(56) Wang, Y. S. Chem. Res. Toxicol. 2008, 21, 276-281. 